\title{
Late Tortonian-Quaternary tectonic evolution of central Sicily: the major role of the strike-slip deformation
}

\author{
STEFANO CATALANO广, FRANCESCO PAVANO, GINO ROMAGNOLI, \\ GIUSEPPE TORTORICI \& LUIGI TORTORICI \\ Dipartimento di Scienze Biologiche, Geologiche e Ambientali - Sezione di Scienze della Terra, Università di Catania, \\ Corso Italia, 57 - 95129 Catania, Italy
}

(Received 8 October 2015; accepted 22 March 2016; first published online 10 July 2017)

\begin{abstract}
We here propose a new kinematic picture of central Sicily based on the results of detailed field mapping of the region, combined with structural analyses and the interpretation of the available literature subsurface data. Our study focused on the tectonic boundary of a structural depression, the Caltanissetta Trough, which is now filled with allochthonous terrains resting on the deep-seated inverted African palaeomargin units. Our data refer to the tectonosedimentary evolution of the thrusttop basins, from Late Tortonian to Quaternary times. The study points out the occurrence of regional E-W-oriented dextral shear zones, cutting the NE-oriented trends of the thrust belt. This new evidence would confirm the major role of the E-W trend in the tectonic inversion of the external portions of the Africa palaeomargin in Sicily. Our results could contribute to a better understanding of the location in Sicily of the tectonic lineaments accommodating the hundreds of kilometres of lateral displacement, caused by the Late Miocene-Quaternary Tyrrhenian Basin opening to the north of the island.
\end{abstract}

Keywords: thrust and fold belt, strike-slip tectonics, thrust-top basin, Africa palaeomargin, central Sicily, Caltanissetta Trough

\section{Introduction}

The Sicily thrust and fold belt developed along the EW-oriented Nubia-Eurasia convergent margin of the Western Mediterranean (Serpelloni et al. 2007) (see inset in Fig. 1). The backbone of the orogenic belt (Bianchi et al. 1987; Roure et al. 1990; Lentini, Carbone \& Catalano, 1994; Catalano et al. 2013b ) consists of the Meso-Cenozoic successions of the inverted African passive margin (Meso-Cenozoic African units in Fig. 1) that are largely covered by a SEverging allochthonous thrust edifice (Numidian Flysch Nappe in Fig. 1), whose sense of transport is parallel to the direction of the plate convergence (Dewey et al. 1989; Hollenstein et al. 2003; D'Agostino \& Selvaggi, 2004) (Fig. 1). Nevertheless, the most impressive tectonic lineament of Sicily consists of a prominent $\mathrm{E}-\mathrm{W}$-oriented crustal ramp (i.e. the $\mathrm{Mt}$ Kumeta-Alcantara Line of Ghisetti \& Vezzani, 1984; KAL in Fig. 1) parallel to the general trend of the plate boundary. The Kumeta-Alcantara Line controls the gross geometry of the collision belt, separating the axial zone (Madonie-Nebrodi Axial Zone in Fig. 1) from the piedmont frontal areas. This structure duplicates the Africa Crust and shows a dextral component of motion. A further E-W oblique (dextral) crustal ramp (Sicanian Mountains thrust front of Monaco, Tortorici \& Catalano, 2000; Tortorici et al. 2001; STF - Sicanian Thrust Front in Fig. 1) breaches the ex-

†Author for correspondence: catalano@unict.it ternal domains of southwestern Sicily, carrying the Meso-Cenozoic African units (Sicanian Thrust Belt in Fig. 1) onto the allochthonous nappes of southern Sicily (Fig. 1). The Sicanian Thrust Front coincides with the northwestern edge of the impressive negative Bouguer anomaly that marks a wide structural depression of central Sicily (Caltanissetta Trough; Roda, 1968; Decima \& Wezel, 1971; Lentini, Carbone \& Catalano, 1994; Lentini et al. 1996) (Fig. 1), hosting the main Messinian and Plio-Pleistocene thrust-top basins of the island. The evidence of the eastward prolongation of the Sicanian Thrust Front along the northern border of the Caltanissetta Trough seems to vanish in central Sicily, where large volumes of allochthonous terrains cover the African units. The definition of the geometry, the kinematics and the evolution of the tectonic lineaments developed at the northern border of the Caltanissetta Trough is still an open, crucial issue to complete the post-Tortonian regional tectonic picture of Sicily.

This paper focuses on the geometry of the structural assemblages bordering the main depocentres located along the northern border of the Caltanissetta Trough, in central Sicily, in order to provide new geological constraints to reconstruct the geometry, the kinematics and the tectonic evolution of the structures that developed along the eastward prolongation of the Sicanian Thrust Front and to establish their role in the larger scale tectonic context of the Sicily collision belt.

Our study is based on the results of the detailed (1:10000 scale) geological mapping of a vast region 


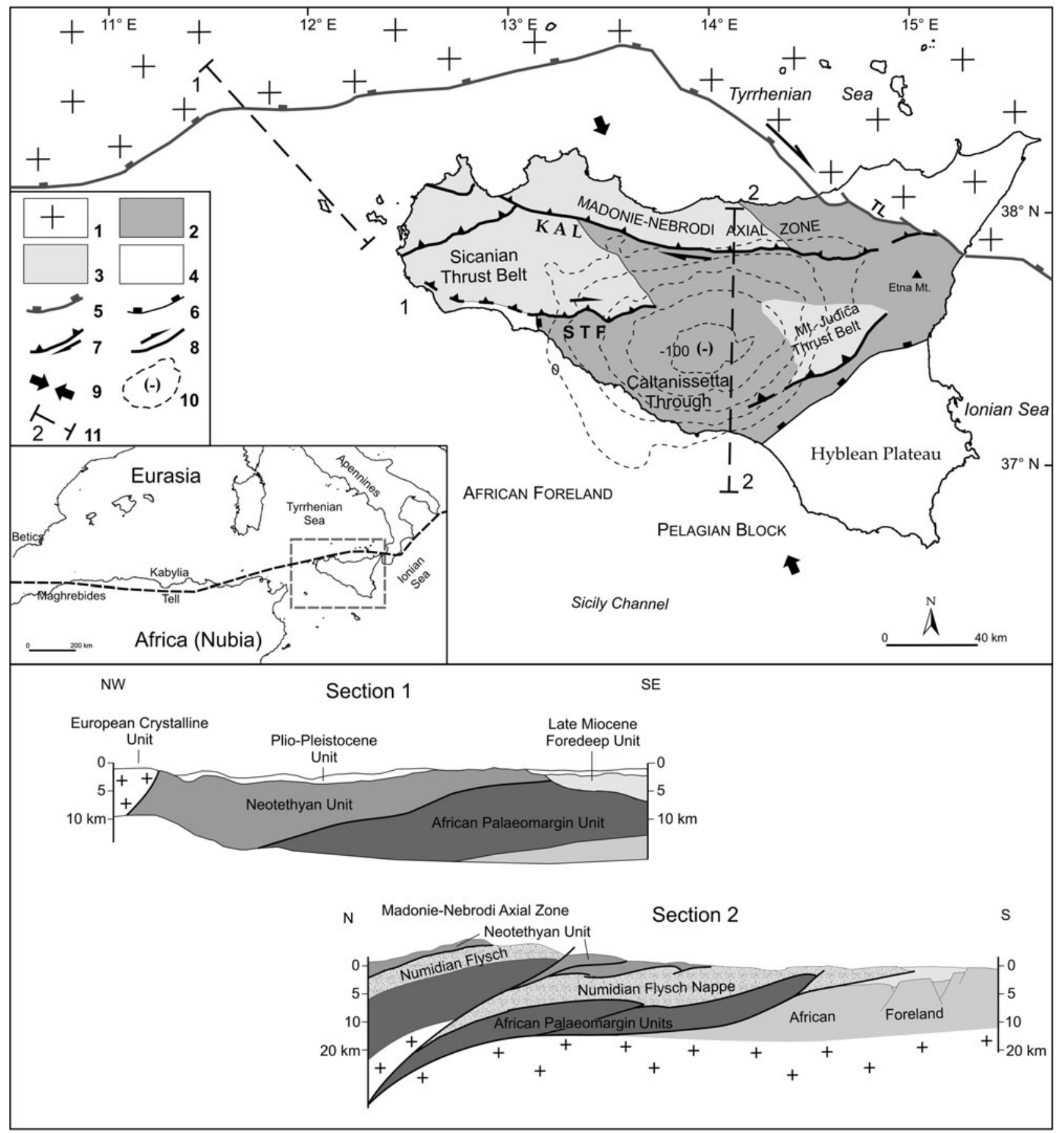

Figure 1. Tectonic sketch map of Sicily showing the main tectonic lineaments of the Sicily Collision Belt and the main tectonic domains: 1 - European Crystalline Units; 2 - Numidian Flysch Nappe; 3 - Meso-Cenozoic African Units; 4 - Foreland sequences; 5 - front of the European Crystalline units; 6 - front of the allochthonous Numidian Flysch Nappe; 7 - thrust: the arrow indicates the strike-slip component of the motion; 8 - strike-slip tectonic lineaments: the arrow indicates the sense of the motion; 9 - direction of Nubia-Eurasia convergence (from Hollenstein et al. 2003); 10 - contour lines of negative gravity anomaly (from 0 to $-100 \mathrm{mGal}$ ) of the Caltanissetta Trough (from Accaino et al. 2011 modified); 11 - trace of schematic geological sections. STF - Sicanian Thrust Front; KAL - Mt Kumeta-Alcantara Line; TL - Taormina Line. The inset portrays the E-W-oriented Nubia-Eurasia plate boundary in the Western Mediterranean (from Serpelloni et al. 2007). The schematic geological sections (see map for location) are modified from Catalano, Infuso \& Sulli (1995) (profile 1) and Lentini et al. (1996) (profile 2).

of central Sicily (see Fig. 2 for location), including the Messinian Corvillo and Mandre basins (CV and MA in Fig. 2) and the Plio-Pleistocene Centuripe Basin (CE in Fig. 2). The new geological map highlights the structural associations that developed during the deposition of the distinct sedimentary sequences that filled these thrust-top depocentres, perched on the allochthonous edifice.

Our study was also supported by the remarkable literature subsurface data (ViDEPI project, 2009-2016; Bello, Franchino \& Merlini, 2000; Maniscalco et al. 2010; Catalano et al. 2013b; Butler et al. 2015), 


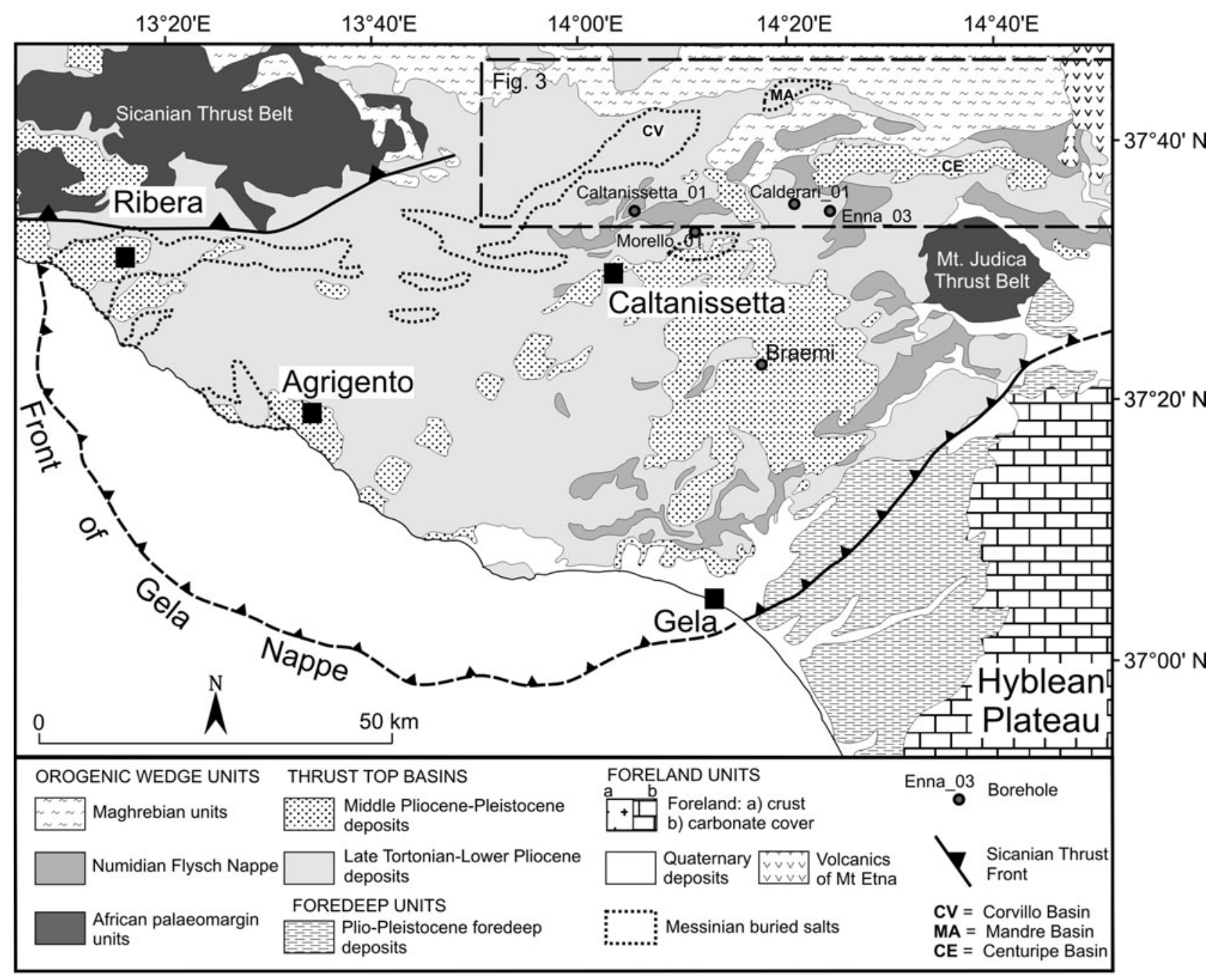

Figure 2. Geological map of the Caltanissetta Trough. Dashed boxes refer to the study area including the Corvillo, Mandre and Centuripe basins. In the map the Messinian buried salt deposits (from Decima \& Wezel, 1971) and the deepest basin-depocentres, represented by Corvillo (CV), Mandre (MA) and Centuripe (CE), are reported. Borehole data derive from ViDEPI project, 20092016.

including some interpreted seismic lines and several stratigraphic logs of boreholes.

\section{Tectonic domains of Sicily}

The Sicily collision belt derives from the positive tectonic inversion of the previous rifted passive margin of Africa (Mascle, 1979; Catalano \& D'Argenio, 1982; Ogniben, 1985; Roure et al. 1990; Tortorici et al. 2001), buried beneath the allochthonous nappes of the Neotethyan accretionary wedge. A complete section of the collision belt is now preserved in the offshore of western Sicily (Catalano, Infuso \& Sulli, 1995). Along this transect (see profile 1 in Fig. 1), the SEverging thrust belt is composed of the allochthonous units that are sandwiched between the Europe-derived crystalline units, at the top, and the Meso-Cenozoic carbonate units of the Africa palaeomargin, at the bottom.

In the Sicily onshore, the E-W trends prevail, owing to the development of the Madonie-Nebrodi Axial
Zone, at the hangingwall of the prominent Mt KumetaAlcantara Line (KAL in Fig. 1) (Ghisetti \& Vezzani, 1982, 1984; Renda et al. 2000; Gueguen et al. 2002), a main dextral thrust ramp, bordering the entire northern Sicily mountain belt. This main structure duplicates the entire Africa Crust with the overriding Neotethyan allochthonous units (Sicilide Complex: Ogniben, 1960; Lentini \& Vezzani, 1978; Lentini, Carbone \& Catalano, 1994 or Neo-Tethyan units: Roure et al. 1990), cutting obliquely the lineaments of the thrust and fold belt. At the hangingwall, the core of the axial zone consists of a culmination of the African palaeomargin units, capped by the Upper Oligocene Lower Miocene Numidian Flysch succession (Lentini \& Vezzani, 1974; Catalano \& D’Argenio, 1982; Bianchi et al. 1987; Pinter et al. 2016).

In the footwall of the axial zone, the tectonic slices of the Neogene-Quaternary edifice extensively crop out. These external domains are mostly composed of the Africa-derived units that culminate in western Sicily (Sicanian Thrust Belt of Fig. 1) and in 
eastern Sicily (Mt Judica Thrust Belt of Fig. 1). In the intermediate region of central Sicily, the Caltanissetta Trough represents a vast triangular-shaped depression of the African palaeomargin units that is clearly indicated by an impressive negative Bouguer anomaly (Fig. 1). The Caltanissetta Trough hosts a huge volume of allochthonous nappes, mostly consisting of detached slices of the Numidian Flysch successions, moved from their original African substratum, that now form a SE-verging imbricated stack (Numidian Flysch Nappe in Fig. 1; Roure et al. 1990), tectonically overlying the deep-seated basinal sequences of the Africa palaeomargin (see profile 2 in Fig. 1; Bianchi et al. 1987; Bello, Franchino \& Merlini, 2000). The frontal portion of the Numidian Flysch Nappe (Gela Nappe; Ghisetti et al. 2009) is emplaced on Lower Pleistocene deposits on top of the carbonate successions of the African Foreland (Pelagian Block in Fig. 1; Bianchi et al. 1987; Roure et al. 1990; Lentini, Carbone \& Catalano, 1994). In western Sicily, the Gela Nappe is interrupted by the E-W-oriented Sicanian Thrust Front (STF in Fig. 1), carrying the Sicanian Thrust Belt onto the inner portions of the Caltanissetta Trough with a dominant dextral component of motion (Monaco, Tortorici \& Catalano, 2000; Tortorici et al. 2001). In eastern Sicily, the Gela Nappe extends to the coastal area of the town of Catania (Torelli et al. 1998; Catalano, Torrisi \& Ferlito, 2004).

The seismic lines across the Caltanissetta Trough (Bello, Franchino \& Merlini, 2000; Catalano et al. $2013 b$ ) indicate that, beneath the Numidian Flysch Nappe, the external part of the depression is floored by the NW-dipping regional monocline of the African Foreland, reaching a maximum depth of $c .7 \mathrm{~km}$ at the centre of the trough (Bello, Franchino \& Merlini, 2000; Ghisetti et al. 2009). Thin-skinned imbricated tectonic slices of the African passive margin mark at depth the inner $\mathrm{E}-\mathrm{W}$-oriented northern margin of the trough.

The analysis of the borehole logs (Ghisetti et al. 2009) indicates that the top of the African succession, buried beneath the Numidian Flysch Nappe, varies in age from Serravallian, in the inner portion of the trough, to Late Tortonian, in the external areas.

At the surface, distinct sedimentary cycles, ranging in age from Late Tortonian to Middle Pleistocene, were deposited within the thrust-top depocentres perched on the allochthonous nappes (Fig. 2; Roure et al. 1990; Lentini, Carbone \& Catalano, 1994; Di Grande \& Giandinoto, 2002).

The Sicily collision zone is interrupted, at the NE corner of the island, by the southern edge of the Calabrian arc (Taormina Line; TL in Fig. 1) (Scandone, 1979; Rossi \& Sartori, 1981; Malinverno \& Ryan, 1986; Ghisetti et al. 1991; Catalano et al. 2012; Malinverno, 2012; Pavano et al. 2015). The arc represents a fragment of the crystalline European margin that is now emplaced at the trailing edge of the Neogene-Quaternary Ionian basin accretion- ary wedge (Rossi \& Sartori, 1981; Polonia et al. 2011).

\section{Caltanissetta Trough units}

The Caltanissetta Trough is prevalently filled with the succession of the Numidian Flysch Nappe, which is now exposed in the main thrust ridges. It consists of basal chaotic varicoloured clays, capped by the Lower Miocene turbiditic deposits of the Numidian Flysch. The sequence evolves to Middle Miocene pelagic marly clays, whose top is progressively younging towards the SE, from the Serravallian to the Upper Tortonian (Ogniben, 1960; Grasso et al. 1995). The basal portion of the Numidian Flysch Nappe is mainly made of pelagic Cretaceous-Lower Oligocene sediments, showing characters of a tectonic mélange with a typical block-in-matrix fabric. The basal mélange is usually exposed at the core of the major rampanticlines. The Upper Oligocene - Lower Miocene turbiditic sequence of the Numidian Flysch is represented by almost regular alternations of brownish clays and yellowish quartzarenites, locally showing extensive stratal disruption. The overlying MiddleUpper Miocene marly clays are diffusely intruded by mud-breccia bodies (Argille Brecciate units; Ogniben, 1954; Monaco \& Tortorici, 1996) fed by diapirs developed from the underlying basal mélange and $\mathrm{Nu}-$ midian Flysch broken formation.

The complete stratigraphic succession of the allochthonous Numidian Flysch Nappe has been drilled, at a maximum depth of $c .6800 \mathrm{~m}$, by several boreholes (e.g. Caltanissetta 01, Morello 01, Braemi 01, Calderari 01, Enna 03 in Fig. 2; Field ViDEPI project, 20092016) located in the inner portion of the Caltanissetta Trough.

The thrust-top basins perched on the allochthonous Numidian Flysch of the Caltanissetta Trough are filled up by distinct syn-tectonic sedimentary cycles (Roda, 1968; Di Grande \& Giandinoto, 2002).

The first cycle is widely distributed all over the $\mathrm{Nu}-$ midian Flysch Nappe and ranges in age from Late Tortonian to Early Pliocene. Its deposition matched the progressive emplacement of the allochthonous $\mathrm{Nu}-$ midian sequences on the African foreland sequence. Along the inner portion of the Caltanissetta Trough, the Upper Tortonian deposits consist of alluvial sandstones, clays and patch reef sediments of the Terravecchia Formation (Schmidt Di Friedberg, 1962) that unconformably cover the internal successions of the Numidian Flysch Nappe. In this area, the Upper Tortonian deposits evolve to Messinian pre-evaporitic and evaporitic successions (Decima \& Wezel, 1971; Roveri et al. 2008). The Messinian deposits form two distinct sequences, separated by a regional unconformity. The lower sequence is made of evaporitic limestones, gypsum and salts, while the upper one mainly consists of gypsum horizons interleaved within prevalent detrital evaporites and coarse-grained clastic deposits. Huge volumes of salts of the first cycle, 
concealed by the clastic deposits of the second cycle, are preserved at the core of the main footwall synclines of the thrust wedge (Lentini et al. 1996) (e.g. Corvillo, $\mathrm{CV}$ in Fig. 2; Mandre, MA in Fig. 2).

A few tens of metres of the Messinian succession, mainly represented by evaporitic limestones and sulfur-bearing calcareous breccias evolving to laminated gypsum, rest on the ancient thrust ridges. The Messinian successions of the Caltanissetta Basin have been related to marginal basins with a relatively deepwater $(300-1000 \mathrm{~m})$ setting, in contrast to the sequences that were deposited in shallow-water conditions, to the north of the Caltanissetta Trough, at the foothills of the axial zone (Roveri et al. 2014). In the more external domains of the Caltanissetta Trough, the top of the Numidian Flysch succession dates back to Late Tortonian time and, consequently, the base of the unconformable deposits coincides with the Messinian basal evaporitic limestones and gypsum.

The Lower Pliocene sediments consist of the marls and the marly limestones of the Trubi Formation that was deposited during the Zanclean flooding, successive to the Messinian Salinity Crisis (Roveri et al. 2008). The Trubi are spread all over the Numidian Flysch Nappe.

A main regional angular unconformity, due to the severe deformation of the Messinian-Early Pliocene levels, marks the base of the regressive deltaic depositional sequences, ranging in age from Late Zanclean to Middle Pleistocene, that filled up the Caltanissetta Trough (Roda, 1968; Di Grande \& Giandinoto, 2002) (Fig. 3). Each sequence consists of a proximal clastic and bioclastic wedge, prograding onto the coeval distal pro-delta marls (Lentini et al. 1996). These sequences were deposited during the progressive emergence of the region, and the related coastal deposits are now terraced at various altitudes on top of the allochthonous units of the Caltanissetta Trough. A different geometry of the Plio-Pleistocene cycles characterizes the region of the Centuripe Basin (CE in Fig. 2). This depocentre, showing an $\mathrm{E}-\mathrm{W}$ orientation, is now isolated to the north of the Mt Judica Thrust Belt. It remained almost fixed from the Zanclean to the Piacenzian period, during which two distinct depositional sequences, including turbiditic sandstones and marly clay levels, were trapped in a very narrow and deep basin, rather than spread on the top of the allochthonous wedge as in the rest of the Caltanissetta Trough.

\section{Geological outlines of the northern border of the Caltanissetta Trough}

The geological map of Figure 3 portrays the main geological features of the northern margin of the Caltanissetta Trough (see Fig. 2 for the location). The study area focuses on the interference zone between the EW-oriented $\left(\mathrm{N} 80-110^{\circ}\right)$ tectonic alignments that developed along the eastward prolongation of the Sicanian Thrust Front and the ENE-trending tectonic features bordering the depocentres of the Corvillo, Mandre and Centuripe basins. This region provides good examples of the geometric relationship between the distinct sets of tectonic features, with an excellent stratigraphic record of the tectonic events from Messinian to Quaternary times. In the examined region, ENE-trending fold and thrust systems deform two main Messinian depocentres. To the west, the Corvillo Basin is filled with a thick Messinian succession, including both the two superimposed evaporitic cycles. The basal cycle consists of Lower Messinian (6.0$5.5 \mathrm{Ma}$; Roveri et al. 2014) carbonates and gypsum evolving to halite and K-salts; the second cycle is composed of Upper Messinian (5.5-5.3 Ma; Roveri et al. 2014) gypsum intercalated within prevalent mudstones and gypsiferous sandstones. The Messinian succession is now preserved in a triangle zone that developed at the footwall of a major ENE-WSW-oriented backthrust system that carries the successions of the $\mathrm{Nu}$ midian Flysch Nappe of the southeastern margin onto the depocentre of the basin. The primary geometry of the back-verging structures is modified by a set of WNW-trending, left-stepping dextral faults that dissects the Numidian Flysch Ridge. To the south of this shear zone, several SE-dipping back-thrusts, located between the villages of Villarosa and Marianopoli, are associated with conjugate, NW-dipping thrusts. In the area of Villarosa, retrowedge and prowedge thrusting defines a $3-5 \mathrm{~km}$ wide box-fold anticline. A very thin Messinian succession, composed of the basal carbonates and gypsum levels, with the overriding unconformable Lower Pliocene marly-limestone levels (Trubi Fm), drapes the anticline (stratigraphic column 1 in Fig. 3). To the north of the dextral shear zone, the margin of the Corvillo Basin culminates in the area of Mt Altesina, where a N-verging imbricated fan of the Numidian Flysch succession is exposed.

The opposite margin of the Corvillo Basin consists of an impressive ENE-WSW-oriented flexure that involves the Numidian Flysch sequence together with the overlying Upper Tortonian marls, the Lower Messinian carbonate and gypsum evaporitic horizons and the clastic deposits of the second Messinian cycle. The flexure corresponds to the forelimb of a wide NEoriented, S-verging anticline, whose hinge zone runs on the Tortonian horizons, cropping out in the region from Marianopoli to Resuttano (Fig. 3). The attitude of the Upper Tortonian - Upper Messinian horizons clearly indicates the progressive closure of the fold during deposition (cross-section A in Fig. 4; see Fig. 3 for location). The Upper Tortonian strata dip towards the SSE with a subvertical attitude. The Lower Messinian levels show an inclination of $c .60^{\circ}$ and the Upper Messinian clastic levels dip with an inclination of c. $50^{\circ}$.

Numerous boreholes of the Corvillo mine concession penetrate the Messinian horizons that infill the basin, drilling more than $1500 \mathrm{~m}$ of evaporites in the depocentral area. This value is mostly due to tectonic duplications of the primary sequence that is pushed 


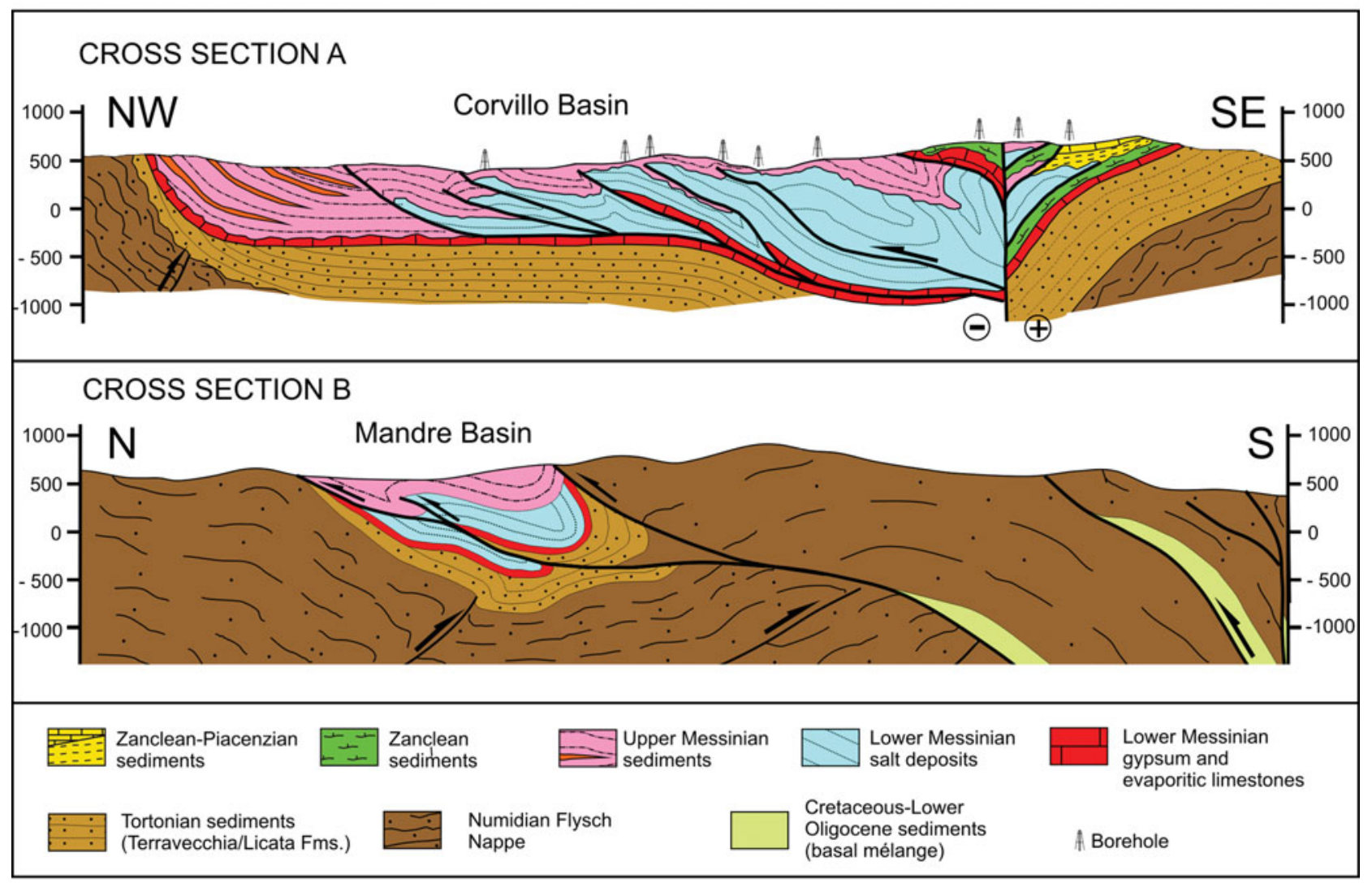

Figure 4. (Colour online) Geological cross-sections across the Corvillo Basin (cross-section A) and the Mandre Basin (cross-section B). For location see traces in Figure 3.

by the back-verging southern margin and extruded towards the northern margin (cross-section $\mathrm{A}$ in Fig. 4). The profile, combining field data with the robust subsurface information, illustrates the geometry of the deposits. The depocentre of the first cycle is markedly shifted to the south, where the salts reach their maximum stratigraphic thickness of $c .600 \mathrm{~m}$ (stratigraphic column 2 in Fig. 3). The salts are largely detached from their primary Lower Messinian substratum and form a series of imbricates that also involve the overriding deposits of the second cycle. A total displacement of $c .14 \mathrm{~km}$ has been estimated to restore the primary geometry of the salt deposits on their basal carbonates and gypsum levels. The depocentre of the second cycle is located at the base of the northwestern border of the basin, where it reaches the maximum stratigraphic thickness of $c .650 \mathrm{~m}$ (stratigraphic column 3 in Fig. 3).

More to the east, the Messinian deposits of the Mandre Basin (see cross-section B in Fig. 4) are preserved at the core of an overturned ENE-directed and NNWverging syncline that developed in the triangle zone at the footwall of the back-verging ramp anticline of the Numidian Flysch. Towards the northeast, the depocentre progressively narrows, due to the intersection with the E-W-trending fault segments of the northern tectonic border of the Caltanissetta Trough. The Mandre Basin abruptly ends along a NW-oriented shear belt, along which sheared lithons of the Upper Messin- ian succession are laterally displaced for $c .15 \mathrm{~km}$ towards the southeast from the cut-off zone of the main depocentre. Approaching the eastern edge of the basin, the thrust ridge at the southern margin tends to bend from the primary $\mathrm{E}-\mathrm{W}$ trend to the NW direction, to align to the bounding shear belt.

The hangingwall of the main back-thrust bordering the Corvillo and the Mandre basins represents the primary physiographic boundary of the Pliocene successions that have filled the thrust-top basins, in the external sectors of the Caltanissetta Trough. The relics of the Pliocene cycles are now preserved in the area of Enna, at an elevation of c. $1000 \mathrm{~m}$ a.s.l., and within the Centuripe Basin, from Leonforte to Centuripe. The Zanclean and Piacenzian deposits of the Enna succession (CARG Project, 1:50 000 Geological Sheet 631 Caltanissetta, 2014) refer to shallow-water clastic and bioclastic wedges, whose pro-delta facies develops in the external-most sectors of the Caltanissetta Trough. A different geometry of the Pliocene succession characterizes the Centuripe Basin, where the deposits of two distinct cycles were trapped in a very narrow and deep basin, reaching a maximum thickness of $c .750 \mathrm{~m}$. The Zanclean-Lower Piacenzian cycle (CARG Project, 1:50 000 Geological Sheet 624 Mt Etna, 2012), reaching a maximum stratigraphic thickness of $c .600 \mathrm{~m}$, is composed of pro-delta marly clay facies evolving to turbiditic sandstone (Lentini et al. 1990). The overlying Piacenzian deposits, 


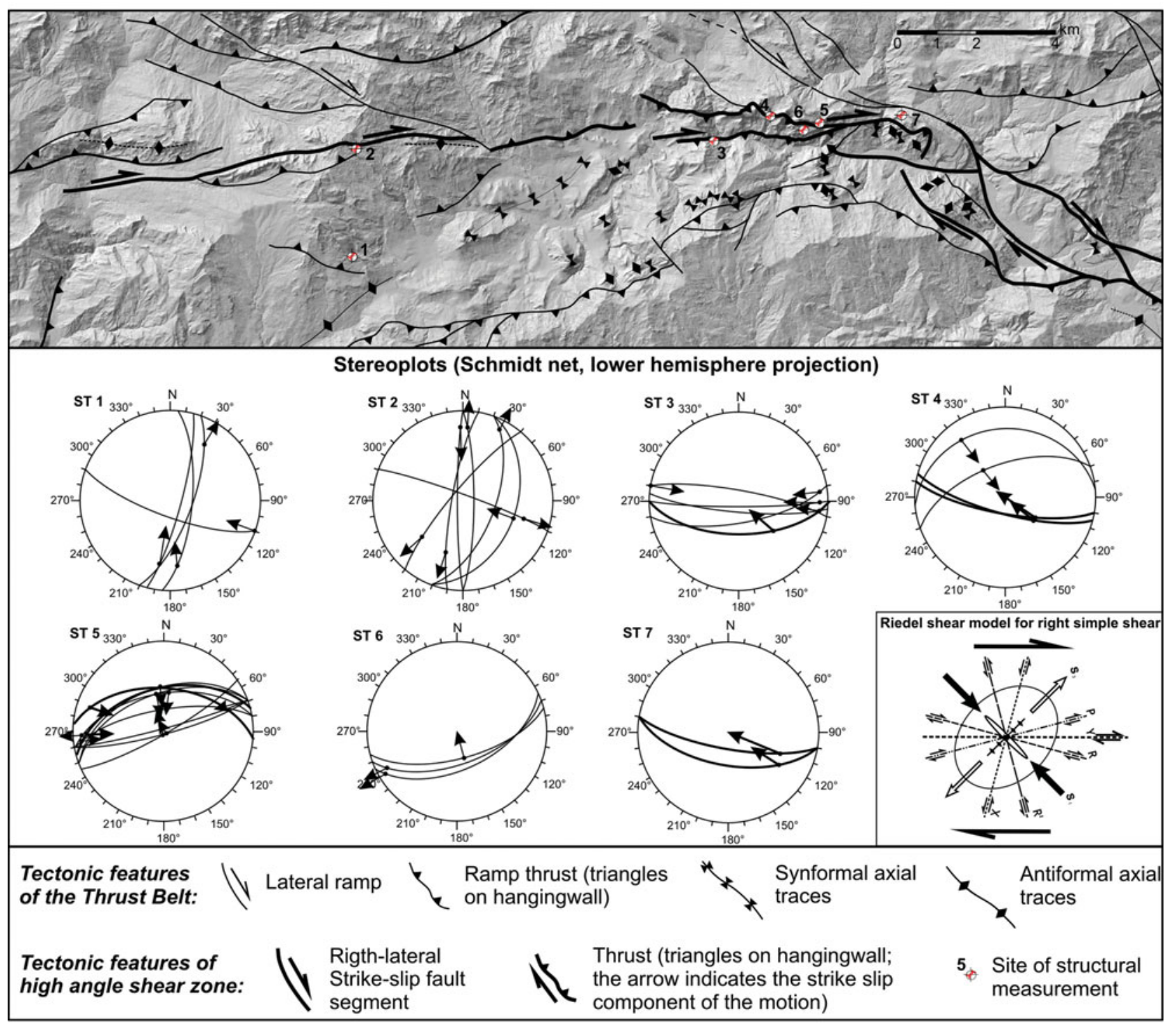

Figure 5. (Colour online) Geometry of the tectonic features of a high-angle shear zone along the northern margin of the Mandre Basin (for location see Fig. 3). The structural data collected in the area, plotted in the stereonets (ST1-7) and the related deformation model (Riedel shear model in the inset), referring to the dextral shearing along the shear zone, are shown.

which are preserved at the core of three distinct open synclines, consist of bioclastic calcarenites in the area of Leonforte-Assoro-Agira (Fig. 3) and quartz-rich sandstones in the area of Centuripe. The deposits of the Centuripe Basin conceal the northern margin of a pre-existing Messinian depocentre, filled with Lower Messinian sulfur-bearing calcareous breccias evolving to laminated gypsum and the Zanclean pelagic marly limestones of the Trubi Formation. This ancient basin was bordered to the north by an E-W-oriented culmination of the Numidian Flysch Nappe, onto which the Zanclean-Piacenzian levels onlap. The entire succession exposed along the southern border of the Centuripe Basin, ranging in age from Messinian to Piacenzian, is intruded by diapirs and sill-like bodies of mud breccias that mark the tectonic contact of the Numidian Flysch Nappe with the African palaeomargin units of the Mt Judica Thrust Belt (see also Figs 1, 2).

\section{Strike-slip tectonics along the northern border of the Caltanissetta Trough}

In the study area, two main E-W-oriented alignments of high-angle faults dissect the ENE-trending tectonic features of the thrust belt. The northern border of the Caltanissetta Trough is bounded by a roughly E$\mathrm{W}$-oriented ramp thrust that developed on the prolongation of the Sicanian Thrust Front. At its easternmost edge, in the area from Alimena to Nicosia, this alignment terminates with a set of N80-trending, right-stepping fault segments that interrupt the Mandre Basin (Fig. 5; see Fig. 3 for location). The detailed structural analyses of this fault belt consisted of mesoscale kinematic investigations of the fault planes, cutting the Numidian Flysch and the Upper Messinian clastic deposits, in seven distinct sites of measurements (see Fig. 5 for location). The collected kinematic data indicate a prevalent dextral strike-slip motion on both principal and secondary fault planes, ranging in 
orientation from N70 to N110. Two distinct sets of faults, trending N70-80 and N100-110, respectively, with rare N90 principal planes, can be distinguished. It is noteworthy that the N70-80 surfaces show two distinct families of kinematic indicators, related to dipslip reverse motion and prevalent dextral motion, respectively. Evidence of left-lateral motion characterizes a set of $\mathrm{N}$ - to N40-trending secondary fault planes. Our data are consistent with the geometry of an E-Woriented dextral shear zone, composed of N70-80 P shear planes, N100-110 R shear planes and N0-40 X shear planes (see inset in Fig. 5).

More to the south, a set of en échelon tectonic features indicate a well-defined $\mathrm{E}-\mathrm{W}$ alignment that extends from the southern margin of the Corvillo Basin to the area of the Centuripe Basin (Fig. 3). To the west, this alignment consists of N120 left-stepping fault segments linked by N50 thrust ramps. The entire fault belt terminates with a W-verging contractional horse tail that developed southwards, from the westernmost tip of the fault zone, in the region between Marianopoli and Villarosa. At the intersection with the fault zone, an impressive dextral displacement of $c .7 \mathrm{~km}$ affects the thrust ridge at the southern margin of the Corvillo Basin. Well-logs in this area (see profile A in Fig. 4) allow the reconstruction of a positive flower structure, affecting horizons as young as Piacenzian. The fault belt terminates to the east with a series of S-verging, N80oriented thrust ramps that form an imbricated stack to the south of Assoro. On the eastern prolongation of the fault belt, a series of right-stepping, en échelon, N80-oriented synclines deform the Pliocene deposits of the Centuripe Basin that show clear evidence of syn-sedimentary deformation. A progressive angular unconformity within the Piacenzian levels accommodated the closure of the limbs, showing a maximum inclination of $c .35^{\circ}$.

\section{Discussion and conclusions}

The new detailed geological mapping of the northern sectors of the Caltanissetta Trough, in central Sicily, presents evidence of the geometry and the kinematics of the tectonic lineaments that have controlled the evolution of the main Messinian and Pliocene depocentres of the region. The collected data provide several new insights to complete the post-Tortonian regional tectonic picture of Sicily. The field analyses present evidence of the existence of two prominent $\mathrm{E}-$ W-trending tectonic alignments that dissect the ENEoriented features of the thrust and fold belt. These E$\mathrm{W}$-trending features consist of dextral shear zones that overlap in a right-stepping arrangement. The two shear zones developed on the prolongation of major tectonic boundaries of culminations of the African palaeomargin units, breaching the overriding allochthonous terrains of the Numidian Flysch Nappe. The northern shear zone, controlling the margin of the Caltanissetta Trough, is on the prolongation of the dextral Sicanian Thrust Front (Monaco, Tortorici \& Catalano, 2000;
Tortorici et al. 2001), at the southern boundary of the Sicanian Thrust System of western Sicily (Fig. 1). The southern shear zone represents the westward prolongation of the tectonic boundary between the Mt Judica Thrust System and the Numidian Flysch Nappe. The seismic lines across the southern shear zone (Bianchi et al. 1987) indicate that the sharp juxtaposition of several thousands of metres of the Numidian Flysch Nappe against the Meso-Cenozoic African succession of the Mt Judica Thrust System corresponds at depth to an abrupt change of the thickness and the magnetic susceptivity of the crust.

In both cases, we can interpret the dextral shear zones as the surface expression of wrench faults rooted in the Africa Crust and imprinted on the overlying Numidian Flysch Nappe. The two shear zones, thus, started to cumulate dextral displacements on the $\mathrm{Nu}-$ midian Flysch Nappe only from Late Tortonian time, after the emplacement of the allochthonous terrains on the African palaeomargin units. At the onset of the dextral shearing, in the interference zone between the two shear zones, the salt depocentres of the Corvillo and Mandre basins developed. The origin of the two basins was associated with a huge tectonic subsidence in a very short time, causing a modification of the sedimentary setting, from the continental-shallow-water conditions of Late Tortonian time (Schmidt Di Friedberg, 1962) to the deep (>300 m) marine conditions during Early Messinian time (Roveri et al. 2014).

Nevertheless, if compared with the results of analogue models reproducing the surface geometry along basement-controlled wrench faulting (Naylor, Mandl \& Sijpesteijn, 1986), the two dextral shear zones show geometric features, denouncing a different stage of evolution. The narrow and sharp northern shear zone, consisting of fault segments sub-parallel to the main shear plane, seems to be more advanced than the southern one, whose en échelon arrangement of the tectonic feature indicates an incipient stage of evolution. This difference would suggest an eastward propagation of the strike-slip tectonics, from the northern to the southern shear zone. Actually, the different geometry of the two alignments could be alternatively explained, taking into account the post-Tortonian geological history of the region, after the emplacement of the Numidian Flysch Nappe on the African palaeomargin units, as summarized in Figure 6. In our reconstruction we propose a kinematic evolution of central Sicily, due to the interference between the dextral shearing, along E-W-oriented alignments buried beneath the allochthonous units, and the thrust motion, along thin-skinned ENE-trending thrust ramps within the allochthonous overburden. During Early Messinian time, the dextral motions along the two E-Woriented buried shear zones caused the propagation of the structure towards the surface, through the overlying Numidian Flysch Nappe. The strike-slip deformation induced the tectonic collapse of the interference zone between the two structures, where the salt depocentres of the Corvillo and Mandre basins developed 


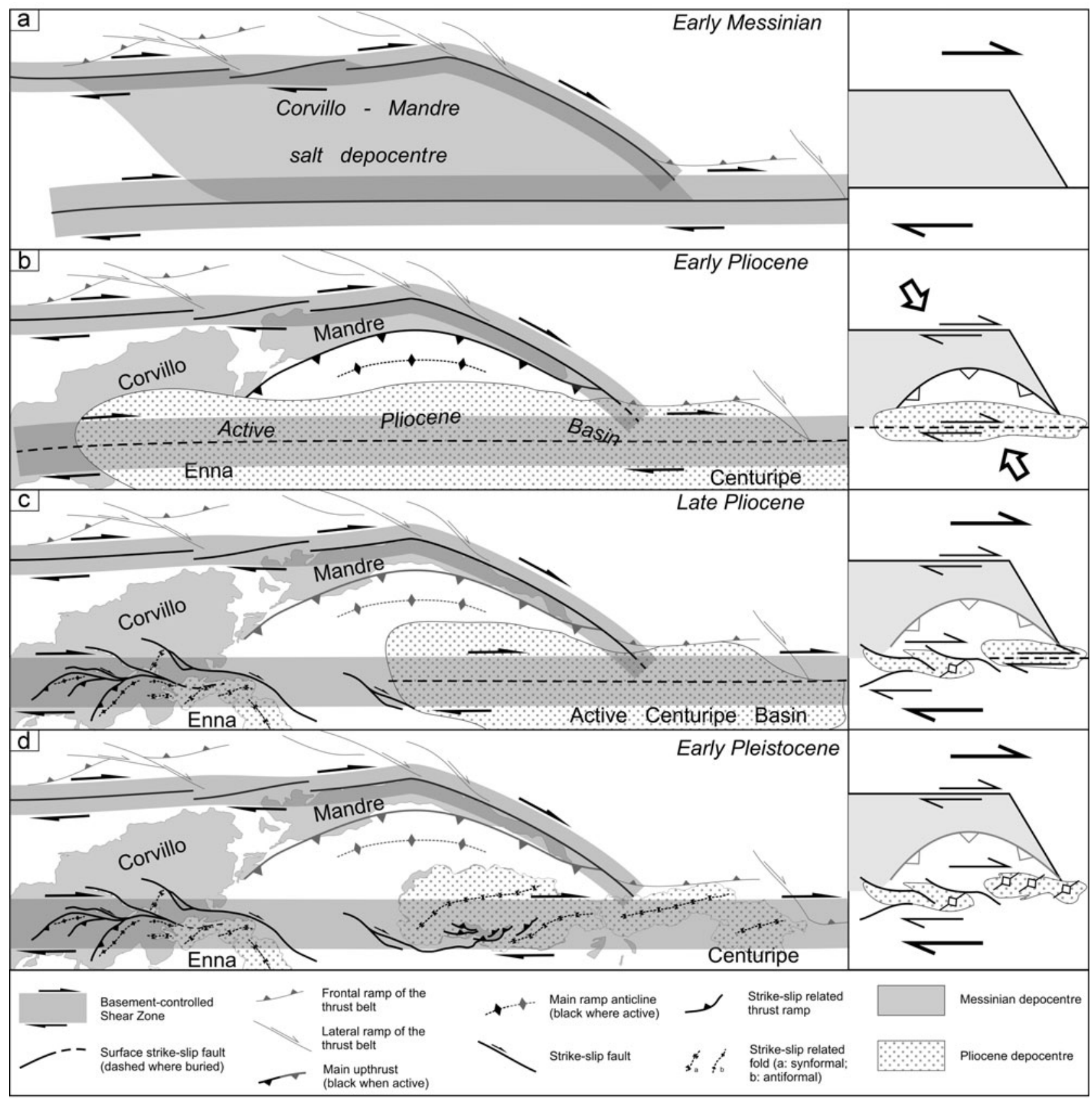

Figure 6. Schematic tectonic evolution of the Corvillo, Mandre and Centuripe basins area (northern margin of the Caltanissetta Trough) from Early Messinian to Early Pleistocene times.

(Fig. 6a). During Early Pliocene time, the restacking of the Numidian Flysch Nappe caused the extensive backverging emplacement of the southern margin of the Corvillo and Mandre basins onto the depocentres and the southward shifting of the active thrust-top basin, along the Enna-Centuripe depocentres (Fig. 6b). The thin-skinned thrust deformation moved the surface features of the southern shear zone $c .15 \mathrm{~km}$ away from the rooted wrench fault, while the northern shear zone was still cumulating dextral displacements. During Late Pliocene and Early Pleistocene times (Fig. 6c, d) a new dextral shear zone developed at the surface, along the Enna-Centuripe alignment, due to the propagation of en échelon features within the Numidian Flysch Nappe resting on the basement wrench fault. This shear zone shows a different geometry, according to the age of the involved deposits. To the west, where it cut through the pre-Pliocene substratum and the deposits of the Zanclean-Piacenzian cycle (e.g. Enna area), the shear zone shows a well-defined array of en échelon fault segments. To the east, where the old shear zone is buried beneath the Piacenzian cycle of the Centuripe Basin, it appears as a set of en échelon folds.

According to the proposed model for central Sicily, the dextral shearing along the E-W-oriented wrench faults could represent, since Late Tortonian time, a permanent and dominant mode of deformation within the inverted passive margin of Africa, interacting with the southeastward sense of tectonic transport, and affecting the overriding allochthonous units. The 


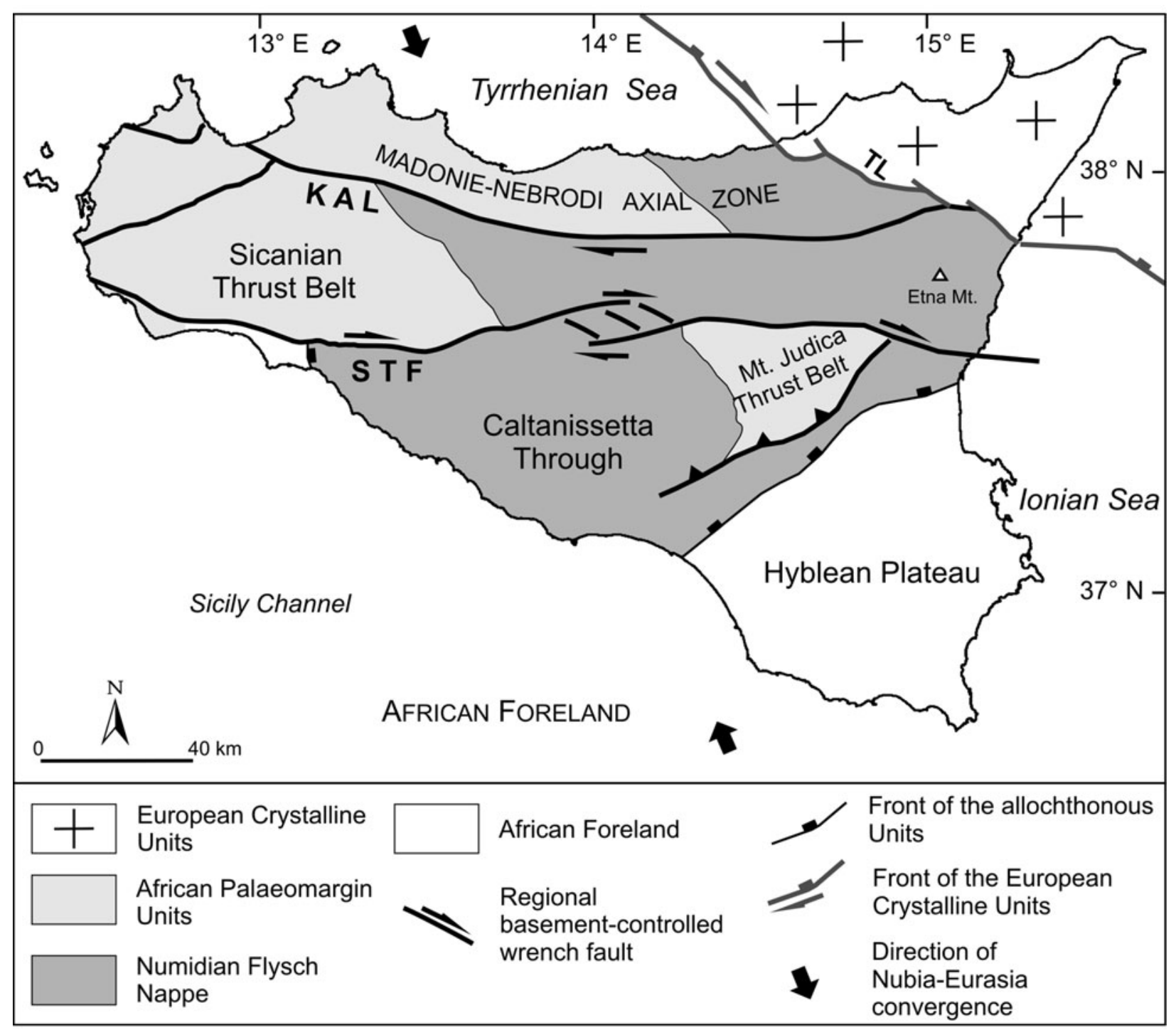

Figure 7. Tectonic sketch map of the main reconstructed strike-slip tectonics and their relationship with the tectonic domains of Sicily.

relatively young age of the shear zones imprinted in the allochthonous terrains would thus refer to the propagation of helicoidal fault surfaces from the deep-seated wrench zone through the piled up nappes, only after their definitive emplacement, rather than represent the evidence of an evolution from thrusting to strike-slip deformation.

The reconstructed long-lived dextral shear zones of central Sicily are part of a longer E-W tectonic alignment, characterized by impressive dextral displacements, that crosses the central portion of the island, as summarized in Figure 7. This alignment includes the E-W-oriented dextral thrust ramp of western Sicily (STF in Fig. 7; Monaco, Tortorici \& Catalano, 2000; Tortorici et al. 2001), the two shear zones of our study and the roughly E-W dextral strike-slip faults cutting through the southern slope of Mt Etna and the Ionian offshore of eastern Sicily (Monaco, De Guidi \& Ferlito, 2010; Bonforte et al. 2011, 2013; Barreca, Bonforte \& Neri, 2013; Catalano et al. 2013a; Gross et al. 2016).
At a regional scale, the existence of this prominent and almost continuous $\mathrm{E}-\mathrm{W}$ tectonic feature is clearly indicated, as well as in the case of the Mt Kumeta Alcantara Line, by the dextral lateral shifting of the major tectonic domain of Sicily, reproduced in Figure 7.

This new kinematic picture is fully consistent with the relative Nubia-Eurasia motion proposed in Catalano et al. (2008), predicting a right-lateral mo-

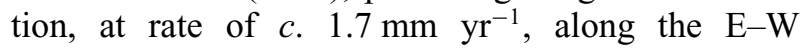
direction.

Regardless, the new tectonic picture sketched in this paper demonstrates the prominent role of the strikeslip deformation in the kinematics that governed the tectonic inversion of the Africa palaeomargin in Sicily. This conclusion could open new perspectives to better locate and define the tectonic lineaments of Sicily that have accommodated the hundreds of kilometres of lateral displacement caused by the Late MioceneQuaternary Tyrrhenian Basin opening and Calabrian arc migration, immediately to the north of the island. 
Acknowledgements. Funding for this research was provided by the COFIN-MIUR 2010-2011 project entitled "Birth and death of oceanic basins: geodynamic processes from rifting to continental collision in Mediterranean and circum-Mediterranean orogens"; National Coordinator Giovanni Capponi, Scientific Coordinator Stefano Catalano.

\section{References}

Accaino, F., Catalano, R., Di Marzo, L., Giustiniani, M., Trinivella, U., Nicolich, R., Sulli, A., Valenti, V. \& MANETTI, P. 2011. A crustal seismic profile across Sicily. Tectonophysics 508, 52-61.

Barreca, G., Bonforte, A. \& Neri, M. 2013. A pilot GIS database of active faults of Mt. Etna (Sicily): a tool for integrated hazard evaluation. Journal of Volcanology and Geothermal Research 251, 170-86.

Bello, M., Franchino, A. \& Merlini, S. 2000. Structural model of Eastern Sicily. Memorie della Società Geologica Italiana 55, 61-70.

Bianchi, F., Carbone, S., Grasso, M., Invernizzi, G., Lentini, F., Longaretti, G., Merlini, S. \& MosTaRdinI, F. 1987. Sicilia orientale: profilo geologico Nebrodi-Iblei. Memorie della Società Geologica Italiana 38, 429-58.

Bonforte, A., Federico, C., Giammanco, S., Guglielmino, F., Liuzzo, M. \& Neri, M. 2013. Soil gases and SAR measurements reveal hidden faults on the sliding flank of Mt. Etna (Italy). Journal of Volcanology and Geothermal Research 251, 27-40.

Bonforte, A., Guglielmino, F., Coltelli, M., Ferretti, A. \& Puglisi, G. 2011. Structural assessment of Mount Etna volcano from permanent scatterers analysis. Geochemistry, Geophysics, Geosystems 12 (2), Q02002. doi: 10.1029/2010GC003213

Butler, R. W. H., Maniscalco, R., Sturiale, G. \& Grasso, M. 2015. Stratigraphic variations control deformation patterns in evaporite basins: Messinian examples, onshore and offshore Sicily (Italy). Journal of the Geological Society, London 172, 113-24.

CARG Project. 2012. Sheet 624 "Mt. Etna" 1:50.000 Scale. Servizio Geologico d'Italia.

CARG Project. 2014. Sheet 631 "Caltanissetta" 1:50.000 Scale. Servizio Geologico d'Italia.

Catalano, S., Bonforte, A., Guglielmino, F., Romagnoli, G., Tarsia, C. \& Tortorici, G. 2013a. The influence of erosional processes on the visibility of Permanent Scatterers Features from SAR remote sensing on Mount Etna (E Sicily). Geomorphology 198, 128-37.

Catalano, R. \& D'Argenio, B. 1982. Schema geologico della Sicilia. In Guida alla Geologia della Sicilia Occidentale (eds R. Catalano \& B. D'Argenio), pp. 9-41. Società Geologica Italiana, Guide Geologiche Regionali.

Catalano, S., De Guidi, G., Romagnoli, G., Torrisi, S., TORTORICI, G. \& TORTORICI, L. 2008. The migration of plate boundaries in SE Sicily: influence on the largescale kinematic model of the African promontory in southern Italy. Tectonophysics 449, 41-62.

Catalano, R., Infuso, S. \& Sulli, A. 1995. Tectonic history of the submerged Maghrebian Chain from the southern Tyrrhenian sea to the pelagian foreland. Terra Nova 7 , 179-88.

Catalano, S., Pavano, F., Romagnoli, G. \& Tortorici, G. 2012. Active tectonic along the Nebrodi-Peloritani boundary (NE Sicily): a new potential seismogenic source. Rendiconti Online della Società Geologica Italiana 22, 44-7.

Catalano, S., Torrisi, S. \& Ferlito, C. 2004. The relationship between Late Quaternary deformation and volcanism of Mt. Etna (eastern Sicily): new evidence from the sedimentary substratum in the Catania region. Journal of Volcanology and Geothermal Research 132, 311-34.

Catalano, R., Valenti, V., Albanese, C., Accaino, F., Sulli, A., Tinivella, U., Gasparo Morticelli, M., Zanolla, C. \& Giustiniani, M. 2013b. Sicily's foldthrust belt and slab roll-back: the SI.RI.PRO. seismic crustal transect. Journal of the Geological Society, London 170, 451-64.

D’Agostino, N. \& Selvaggi, G. 2004. Crustal motion along the Eurasia-Nubia plate boundary in the Calabrian arc and Sicily and active extension in the Messina Straits from GPS measurements. Journal of Geophysical Research 109, B11402. doi: 10.1029/2004JB002998.

Decima, A. \& Wezel, F. C. 1971. Osservazioni sulle evaporiti messiniane della Sicilia centro-meridionale. Rivista Mineraria Siciliana 130-132, 172-87.

Dewey, J. F., Helman, M. L., Turco, E., Hutton, D. H. W. \& KNOTT, S. D. 1989. Kinematics of the western Mediterranean. In Alpine Tectonics (eds M. P. Coward, D. Dietrich \& R. G. Park), 265-83. Geological Society of London, Special Publication no. 45.

Di Grande, A. \& Giandinoto, V. 2002. Plio-Pleistocene sedimentary facies and their evolution in centre-southeastern Sicily: a working hypothesis. EGU Stephan Mueller Special Publication Series 1, 211-21.

Ghisetti, F. C., Gorman, A. R., Grasso, M. \& Vezzani, L. 2009. Imprint of foreland structure on the deformation of a thrust sheet. The Plio-Pleistocene Gela Nappe (southern Sicily, Italy). Tectonics 28, TC4015. doi: 10.1029/2008TC002385.

Ghisetti, F., Pezzino, A., Atzori, P. \& Vezzani, L. 1991. Un approccio strutturale per la definizione della Linea di Taormina: risultati preliminari. Memorie della Società Geologica Italiana 47, 273-89.

GhisetTi, F. C. \& Vezzani, L. 1982. Different styles of deformation in the Calabrian Arc (Southern Italy): implications for a seismotectonic zoning. Tectonophysics $\mathbf{8 5}$, 149-65.

GhisetTi, F. C. \& Vezzani, L. 1984. Thin-skinned deformations of the Western Sicily thrust belt and relationships with crustal shortening: mesostructural data on the Mt. Kumeta Alcantara. Bollettino della Società Geologica Italiana 103, 129-57.

Grasso, M., Miuccio, G., Maniscalco, R., Garofalo, P., La Manna, F. \& Stamilla, R. 1995. Plio-Pleistocene structural evolution of the western margin of the Hyblean plateau and the Maghrebian foredeep, SE Sicily: implications for the deformational history of the Gela Nappe. Annales Tectonicae 9, 7-21.

Gross, F., Krastel, S., Geersen, J., Behrmann, J. H., Ridente, D., Chiocci, F. L., Bialas, J., Papenberg, C., Cukur, D., Urlaub, M. \& Micallef, A. 2016. The limits of seaward spreading and slope instability at the continental margin offshore Mt Etna, imaged by highresolution 2D seismic data. Tectonophysics 667, 63-76.

Gueguen, E., Tavarnelli, E., Renda, P. \& Tramutoli, M. 2002. The geodynamics of the southern Tyrrhenian Sea margin as revealed by integrated geological, geophysical and geodetic data. Bollettino della Società Geologica Italiana 1 (1), 77-85.

Hollenstein, Ch., Kahle, H.-G., Geiger, A., Jenny, S., Geos, S. \& Giardini, D. 2003. New GPS constraints 
on the Africa-Europe plate boundary zone in southern Italy. Geophysical Research Letter 30 (18), 1935. doi: 10.1029/2003GL017554.

Lentini, F., Carbone, S. \& Catalano, S. 1994. Main structural domains of the central Mediterranean region and their Neogene tectonic evolution. Bollettino di Geofisica Teorica ed Applicata 36 (141-144), 103-25.

Lentini, F., Carbone, S., Catalano, S. \& Grasso, M. 1996. Elementi per la ricostruzione del quadro strutturale della Sicilia orientale. Memorie della Società Geologica Italiana 51, 179-95.

Lentini, F., Carbone, S., Catalano, S., Grasso, M. \& Monaco, C. 1990. Principali elementi strutturali del Thrust Belt Appenninico-Maghrebide in Sicilia centroorientale. Memorie della Società Geologica Italiana 45, 495-502.

Lentini, F. \& Vezzani, L. 1974. Carta Geologica delle Madonie (Sicilia centro-settentrionale) alla Scala 1:50.000. Firenze: L.A.C.

Lentini, F. \& VeZZANI, L. 1978. Tentativi di elaborazione di uno schema strutturale della Sicilia orientale. Memorie della Società Geologica Italiana 19, 495-500.

Malinverno, A. 2012. Evolution of the Tyrrhenian SeaCalabrian arc system: the past and the present. Rendiconti Online della Società Geologica Italiana 21 (1), 11-15.

Malinverno, A. \& Ryan, W. B. F. 1986. Extension in the Tyrrhenian Sea and shortening in the Apennines as a result of arc migration driven by sinking of the lithosphere. Tectonics 5, 227-45.

Maniscalco, R., De Guidi, G., Pedley, M., Sturiale, G. \& Grasso, M. 2010. Geological map of the Corvillo and Mandre basins (Caltanissetta Basin, Central Sicily): explanatory notes. Italian Journal of Geosciences 129 (2), 316-26.

MAsCle, G. 1979. Ėtude géologique des Monti Sicani. Memorie della Rivista Italiana di Paleontologia e Stratigrafia 16, 1-431.

Monaco, C., De Guidi, G. \& Ferlito, C. 2010. The morphotectonic map of Mt. Etna. Italian Journal of Geosciences (Bollettino della Società Geologica Italiana) 129 (3), 408-28.

Monaco, C. \& Tortorici, L. 1996. Clay diapirs in Neogene-Quaternary sediments of central Sicily: evidence for accretionary processes. Journal of Structural Geology 18, 1265-9.

Monaco, C., Tortorici, L. \& Catalano, S. 2000. Tectonic escape in the Sicanian Mountains (Western Sicily). Memorie della Società Geologica Italiana 55, 1725.

Naylor, M. A., Mande, G. \& Sijpesteijn, C. H. K. 1986. Fault geometries in basement-induced wrench faulting under different initial stress states. Journal of Structural Geology 8 (7), 737-52.

Ogniben, L. 1954. Le Argille Brecciate Siciliane. Memorie degli Istituti di Geologia e Mineralogia dell'Università di Padova 18, 1-92.

Ogniben, L. 1960. Nota illustrativa dello schema geologico della Sicilia nord-orientale. Rivista Mineraria Siciliana 64-65, 183-212.

Ogniben, L. 1985. Relazione sul Modello Geodinamico Conservativo della Regione Italiana, Commissione ENEA-ENEL per lo Studio dei Problemi Sismici Connessi con la Realizzazione di Impianti Nucleari. Roma: ENEA, 357 pp.
Pavano, F., Romagnoli, G., Tortorici, G. \& Catalano, S. 2015. Active tectonics along the Nebrodi-Peloritani boundary in northeastern Sicily (Southern Italy). Tectonophysics 659, 1-11.

Pinter, P. R., Butler, R. W. H., Hartley, A. J., Maniscalco, R., Baldassini, N. \& Di Stefano, A. 2016. The Numidian of Sicily revisited: a thrustinfluenced confined turbidite system. Marine and Petroleum Geology 78, 291-311.

Polonia, A., Torelli, L., Mussoni, P., Gasperini, L., Artoni, A. \& Klaeschen, D. 2011. The Calabrian Arc subduction complex in the Ionian Sea: regional architecture, active deformation, and seismic hazard. Tectonics 30, TC5018. doi: 10.1029/2010TC002821.

Renda, P., Tavarnelli, E., Tramutoli, M. \& Gueguen, E. 2000. Neogene deformations of northern Sicily, and their implications for the geodynamics of the Southern Tyrrhenian Sea margin. Memorie della Società Geologica Italiana 55, 53-9.

RodA, C. 1968. Geologia della tavoletta Pietraperzia (Prov. Caltanissetta ed Enna, F. 268, III-NE). Atti dell'Accademia Gioenia di Scienze Naturali in Catania S. 6, 19, 145-254.

Rossi, S. \& SARTORI, R. 1981. A seismic reflection study of the external Calabrian arc in the northern Ionian Sea (Eastern Mediterranean). Marine Geophysical Research 4, 403-26.

Roure, F., Howell, D. G., Muller, C. \& Moretti, I. 1990. Late Cenozoic subduction complex of Sicily. Journal of Structural Geology 12, 259-66.

Roveri, M., Flecker, R., Krijgsman, W., Lofi, J., Lugli, S., Manzi, V., Sierro, F. J., Bertini, A., Camerlenghi, A., De Lange, G., Govers, R., Hilgen, F. J., Hübscher, C., Meijer, P. Th. \& Stoica, M. 2014. The Messinian Salinity Crisis: past and future of a great challenge for marine sciences. Marine Geology 352, $25-58$.

Roveri, M., Lugli, S., Manzi, V. \& Schreiber, B. C. 2008. The Messinian Sicilian stratigraphy revisited: new insights for the Messinian salinity crisis. Terra Nova 20, 483-8.

Scandone, P. 1979. Origin of the Tyrrhenian Sea and Calabrian arc. Bollettino della Società Geologica Italiana $\mathbf{9 8}$, 27-36.

Schmidt Di Friedberg, P. 1962. Introduction a la geologie petroliere de la Sicile. Revue de l'Institut Francais du Petrole 17 (5), 635-68.

Serpelloni, E., Vannucci, G., Pondrelli, S., Argnani, A., Casula, G., Anzidei, M., Baldi, P. \& Gasperini, I. 2007. Kinematics of the Western Africa-Eurasia plate boundary from focal mechanisms and GPS data. Geophysical Journal International 169, 1180200.

Torelli, L., Grasso, M., Mazzoldi, G. \& Peis, D. 1998. Plio-Quaternary tectonic evolution and structure of the Catania foredeep, the northern Hyblean Plateau and the Ionian shelf (SE Sicily). Tectonophysics 298, 20921.

Tortorici, L., Monaco, C., Mazzoli, S. \& Bianca, M. 2001. Timing and modes of deformation in the western Sicilian thrust system (southern Italy). Journal of Petroleum Geology 24, 191-211.

ViDEPI PROJECT - Visibility of Petroleum Exploration Data in Italy. 2009-2016. http://unmig.sviluppoeconomico. gov.it/videpi/videpi.asp 